\title{
Supplementary Information: \\ Identification and Quantitative Analysis of Smoldering and Flaming Combustion of Radiata Pine
}

H. Wang, P. J. van Eyk, P. R. Medwell, C. H. Birzer, Z. F. Tian, M. Possell

\section{Description of control volume for the kinetics parameters analysis and energy balance analysis}

The ignition stage is the reactions of the top layer of fuel bed (fixed control volume), which is around TC1 (Figure 1). The ignition stage of smouldering and flaming combustion were chosen according to the TC1 temperature increase rate and TC2 temperatures. The ignition stage starts when the TC1 temperature rapidly increases, and this indicates the onset of strong exothermic reactions at the surface of fuel bed. The TC1 temperature was used as the temperature of the top layer; and the mass loss is caused by the pyrolysis and char combustion of the top layer. The TC2 temperature was used to define the end of the ignition stage, as the thermocouple TC2 was located about $10 \mathrm{~mm}$ below the top layer of the fuel bed. So the TC2 temperature can be used to indicate the layer below the control volume. For example, if the TC2 temperature is high, then this indicates that the reacting layer is close to the thermocouple TC2; and the reactions are not limited to the top layer fuel bed (control volume). In this analysis, the ignition stage ends when the TC2 temperature reaches $100^{\circ} \mathrm{C}$.

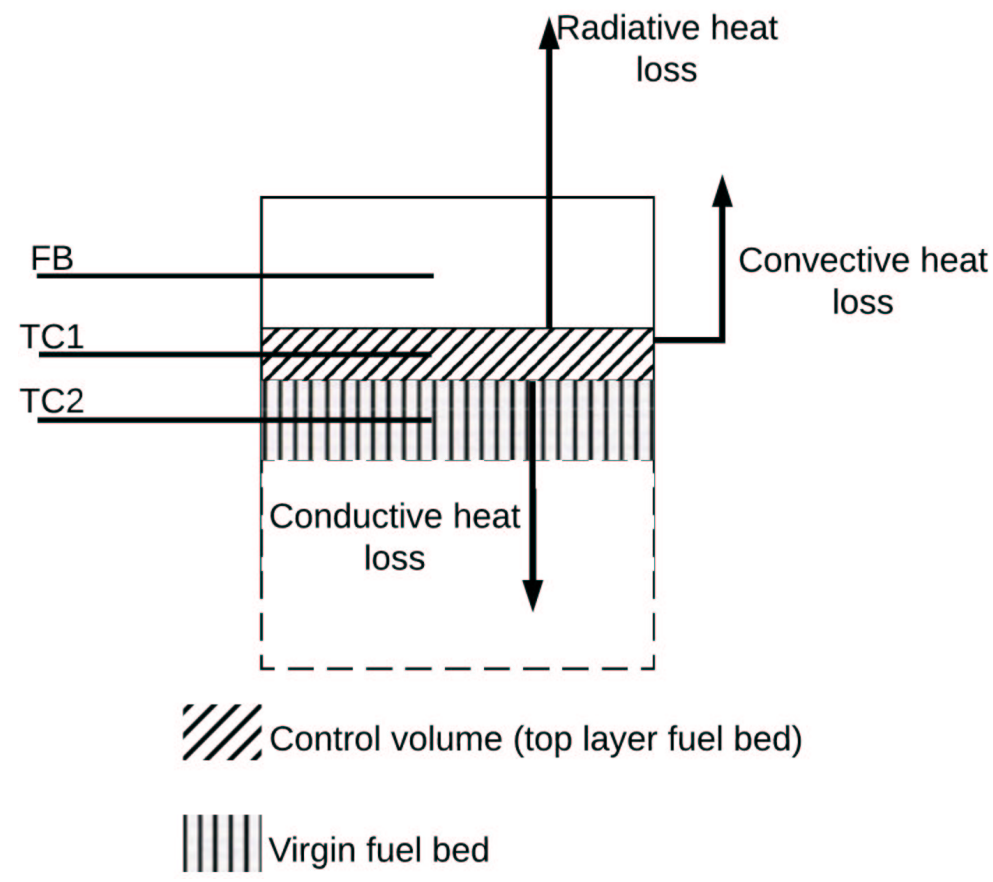

Figure 1: Schematic diagram of the reactor indicating the control volume

\section{Simplified energy balance assumptions and analysis}

The assumptions made for the simplified model are listed here:

1. The gas temperature was assumed to be uniform above the fuel bed, and the temperature of gas was equal to the freeboard(FB) temperature. 
2. The compositions of the product gas include $\mathrm{O}_{2}, \mathrm{CO}, \mathrm{CO}_{2}, \mathrm{~N}_{2} \cdot \mathrm{C}_{x} \mathrm{H}_{y} \mathrm{O}_{z}$ represents volatiles and $\mathrm{H}_{2} \mathrm{O}$ in the product gas.

3. The emissivity of the fuel bed surface was assumed to be 0.924. Lopez et al.(2013)Lopez, Basterra, Acuna, and Casado

4. The temperature in the top layer of the fuel bed is equal to the TC1 temperature, as which is embedded in the the top layer of the fuel bed.

5. The heat loss through the reactor wall was assumed to be natural convective heat loss, and the temperature of the reactor wall around the top layer fuel bed is assumed to be the same as the top layer fuel temperature, i.e. TC1 temperature. The ambient air temperature was assumed to be $25^{\circ} \mathrm{C}$.

6. The temperature of the fuel bed under the top layer is equal to the TC2 temperature, as TC2 was located below the top layer of the fuel bed.

A sensitivity analysis of the heat release rate to changes in emissivity and ambient temperature was performed. The heat release per unit mass of fuel reduces by $7.7 \%$ for smouldering combustion and $7.0 \%$ for flaming combustion, respectively, when the emissivity is decreased from 0.95 to 0.75 . The heat release per unit mass of fuel reduces by $1.1 \%$ for smouldering combustion and $0.6 \%$ for flaming combustion, respectively, when the ambient temperature increases from $25^{\circ} \mathrm{C}$ to $40^{\circ} \mathrm{C}$.

The energy balance analysis for the ignition stage was based on a simplified energy balance:

$$
\text { Energy }_{\text {fuel }}+\text { Heat }_{\text {initial,gas }}=\text { Heat }_{\text {final,gas }}+\text { Heat }_{\text {loss }}
$$

The heat input was calculated as:

$$
\text { Heat }_{\text {in }}=H R R \times t_{\text {ignition }}+\int \sum_{i} \dot{m}_{i}(t)\left[\bar{h}_{g}^{\circ}+C_{p}\left(T_{\text {gas }}-T_{\text {ref }}\right)\right] d t
$$

The terms in Equation (2) are given below:

\begin{tabular}{|c|l|c|}
\hline Term & Comments & Units \\
\hline$H R R$ & $\begin{array}{l}\text { The average heat release rate during } \\
\text { the ignition stage. }\end{array}$ & $\mathrm{W}$ \\
\hline$t_{\text {ignition }}$ & The duration of the ignition stage. & $\mathrm{s}$ \\
\hline$\sum_{i} \dot{m}_{i}(t)\left[\bar{h}_{g}^{\circ}+C_{p}\left(T_{\text {gas }}-T_{\text {ref }}\right)\right]$ & $\begin{array}{l}\text { This is the sum of the enthalpy of for- } \\
\text { mation and the sensible heat of gases } \\
\text { at the beginning of the ignition stage. } \\
\text { The reference temperature was as- } \\
\text { sumed to be } 25^{\circ} \text { C. }\end{array}$ & $\mathrm{W}$ \\
\hline$\dot{m}_{i}$ & $\begin{array}{l}\text { Mass flow rate of gases, e.g. } \mathrm{O}_{2}, \mathrm{CO}, \\
\text { CO } \text {. }\end{array}$ & $\mathrm{g} \cdot \mathrm{s}^{-1}$ \\
\hline $\bar{h}_{g}^{\circ}$ & $\begin{array}{l}\text { Enthalpy of formation of gases at } \\
25^{\circ} \text { C. }\end{array}$ & $\mathrm{J} \cdot \mathrm{g}^{-1}$ \\
\hline$C_{p}$ & $\begin{array}{l}\text { Specific heat capacity at } 25^{\circ} \mathrm{C} \text {. } \\
\mathrm{T} \cdot \mathrm{g}^{-1} \cdot \mathrm{K}^{-1}\end{array}$ & ${ }^{\circ} \mathrm{C}$ \\
\hline$T_{\text {gas }}$ & $\begin{array}{l}\text { The product gas temperature. This } \\
\text { term was obtained based on the free- } \\
\text { board temperature. }\end{array}$ & \\
\hline & &
\end{tabular}

The heat output was calculated as:

$$
\text { Heat }_{\text {out }}=\int \sum_{i} \dot{m}_{i}(t)\left[\bar{h}_{g}^{\circ}+C_{p}\left(T_{\text {gas }}-T_{r e f}\right)\right] d t
$$


The heat losses were calculated as:

$$
\text { Heat }_{\text {loss }}=Q_{\text {radiation }}+Q_{\text {reactor }}+Q_{\text {fuelbed }}
$$

The terms in Equation (4) are given below:

\begin{tabular}{|l|l|c|}
\hline Term & Comments & Units \\
\hline$Q_{\text {radiation }}$ & The radiative heat loss through the surface of fuel bed. & $\mathrm{J}$ \\
\hline$Q_{\text {reactor }}$ & The convectional heat loss through the reactor wall to ambient. & $\mathrm{J}$ \\
\hline$Q_{\text {fuelbed }}$ & The conductive heat loss through the fuel bed below the control volume. & $\mathrm{J}$ \\
\hline
\end{tabular}

According to the ultimate analysis of the pine chips (Table 1 in the paper), the chemical formula for the pine chips sample can be represented as $\mathrm{CH}_{1.446} \mathrm{O}_{0.062} \mathrm{~N}_{0.003}$. The smouldering combustion process can be described by a single-step reaction as below:

$$
\mathrm{CH}_{1.446} \mathrm{O}_{0.062} \mathrm{~N}_{0.003}+\alpha \cdot\left(0.21 \times \mathrm{O}_{2}+0.79 \times \mathrm{N}_{2}\right) \rightarrow \beta \cdot \mathrm{CO}+\gamma \cdot \mathrm{CO}_{2}+\delta \cdot \mathrm{O}_{2}+\varepsilon \cdot \mathrm{N}_{2}+\zeta \cdot\left(\mathrm{C}_{x} \mathrm{H}_{y} \mathrm{O}_{z}\right)
$$

\begin{tabular}{|c|l|}
\hline Coefficient & Comments \\
\hline$\alpha$ & This value is based on the input air flow rate. \\
\hline$\beta$ & This value is based on the measurements of $\mathrm{CO}$ concentration. \\
\hline$\gamma$ & This value is based on the measurements of $\mathrm{CO}_{2}$ concentration. \\
\hline$\delta$ & This value is based on the measurements of $\mathrm{O}_{2}$ concentration. \\
\hline$\varepsilon$ & $\begin{array}{l}\text { This value is a constant, as it is assumed that the nitrogen in the input } \\
\text { air does not participate in reactions. }\end{array}$ \\
\hline$\zeta$ & $\begin{array}{l}\mathrm{C}_{x} \mathrm{H}_{y} \mathrm{O}_{z} \text { is used to balance the single chemical reaction. The value of } \zeta \\
\text { is calculated by mass difference. }\end{array}$ \\
\hline
\end{tabular}

\section{References}

Lopez et al.(2013)Lopez, Basterra, Acuna, and Casado. Lopez, G.; Basterra, L.; Acuna, L.; Casado, M. Journal of Nondestructive Evaluation 2013, 32, 172-176. 